\title{
Review
}

\section{Do We Know the Optimal Oxygen Concentration for Resuscitating a Premature Newborn?}

\author{
Vasantha H.S. Kumar, MD* \\ Department of Pediatrics, Division of Neonatology, John R. Oishei Children's Hospital, University at Buffalo, $5^{\text {th }}$ Floor, I00I Main Street, Buffalo, NY I4203, USA
}

\section{*Corresponding author}

Vasantha H.S. Kumar, MD

Associate Professor, Department of Pediatrics, Division of Neonatology, John R. Oishei Children's Hospital, University at Buffalo, $5^{\text {th }}$ Floor, I00I Main Street, Buffalo, NY 14203, USA; Tel. + I 716323 0260; Fax: + I 716323 0294; E-mail: vkumar@upa.chob.edu

\section{Article information}

Received: October 21 ${ }^{\text {st }}, 2017$; Accepted: November 13 ${ }^{\text {th }}, 2017$; Published: November $13^{\text {th }}, 2017$

\section{Cite this article}

Kumar VHS. Do we know the optimal oxygen concentration for resuscitating a premature newborn? Pediatr Neonatal Nurs Open J. 2017; 5(I): 6-10. doi: $10.17 \mid 40 / \mathrm{PNNOJ}-5-127$

\begin{abstract}
Fetus develops in a relatively hypoxemic environment in utero; however, extremely premature infants need supplemental oxygen soon after birth at resuscitation. Reduced antioxidant defenses predisposes the premature infant to toxic effects of oxygen such as bronchopulmonary dysplasia (BPD) and brain injury. Guidelines were published in 2010 regarding oxygen concentrations to be administered along with the targeted oxygen saturations $\left(\mathrm{SpO}_{2}\right)$ in the first ten minutes after birth in both term and premature infants. Since 2010, there is a widespread tendency to use lower fraction of inspired oxygen $(\leq 0.3)$ at birth. Recent studies and meta-analysis do not provide sufficient evidence to indicate that initiating resuscitation with lower oxygen concentration $(\leq 30 \%$ $\mathrm{O}_{2}$ ) at birth decrease BPD or other clinical outcomes in premature neonates. On the other hand, it is of concern that, it may increase mortality particularly in infants $<28$ weeks gestational age with no demonstrable benefit on clinical outcomes. Did the pendulum swing too quickly from $100 \% \mathrm{O}_{2}$ to $21 \% \mathrm{O}_{2}$ for resuscitation of these infants? Should we initiate resuscitation of all premature infants with $>21 \% \mathrm{O}_{2}$, meaning a change in neonatal resuscitation guidelines or conduct a rigorous multicenter trial to address this dilemma.

\section{Keywords}

Resuscitation; Oxygen; $\mathrm{SpO}_{2}$; Premature infants.

\section{Abbreviations}

NRP: Neonatal Resuscitation Program; GA: Gestational Age; HR: Heart Rate; NICUs: Neonatal Intensive Care Units; AOR: Adjusted Odds Ratio; ROP: Retinopathy of Prematurity; BPD: Bronchopulmonary Dysplasia; HMD: Hyaline Membrane Disease; VEGF: Vascular Eendothelial Growth Factor; HIF: Hypoxia Inducible Factor; DSMB: Data Safety Monitoring Board.
\end{abstract}

\section{INTRODUCTION}

$\mathrm{O}$ ptimal management of oxygen during neonatal resuscitation has become particularly important, as insufficient or excessive oxygenation can be harmful to the newborn infant. ${ }^{1}$ In 2010, neonatal resuscitation program (NRP) issued guidelines for oxygen concentrations administered at birth based on nomograms for oxygen saturation targets in term and premature infants. ${ }^{1}$ Studies have defined the percentiles of oxygen saturation $\left(\mathrm{SpO}_{2}\right)$ as a function of time from birth in uncompromised babies born at term. ${ }^{2,3}$ The guidelines recommend that the goal in babies resuscitated at birth, whether born at term or preterm, should be an oxygen saturation value in the interquartile range of preductal saturations measured in bealthy term babies following vaginal birth at sea level. ${ }^{1}$ Furthermore, the guidelines recommend preductal $\mathrm{SpO}_{2}$ of $60-65 \%$ at 1 $\min ; 65-70 \%$ at $2^{\text {nd }} \min ; 70-75 \%$ at $3^{\text {rd }} \min ; 75-80 \%$ at $4^{\text {th }}$ min and $80-85 \%$ at the end of 5 minutes. Recommended $\mathrm{SpO}_{2}$ target from five to ten minutes after birth was $85-95 \%$. ${ }^{1}$ The $\mathrm{SpO}_{2}$ guidelines were applicable for both term and premature infants, by initiating resuscitation with air or blended oxygen and titrating the oxygen concentration to obtain a $\mathrm{SpO}_{2}$ in the target range by pulse oximetry. ${ }^{1}$ Recently, the guidelines were updated to achieve saturation target range by initiating resuscitation with a low oxygen concentration $\left(21 \% \mathrm{O}_{2}-30 \% \mathrm{O}_{2}\right)$ in premature infants and recommended against 
initiating resuscitation with high supplementary oxygen concentration $\left(65 \% \mathrm{O}_{2}-100 \% \mathrm{O}_{2}\right)^{4}$ in these infants. However, the concentration increased to $100 \% \mathrm{O}_{2}$ in a bradycardic infant (heart rate $<60 /$ min) after 90 seconds of resuscitation with a lower concentration of oxygen, until the heart rate recovers to normal (HR>100/min). The recommendation to use lower concentration of oxygen at resuscitation of preterm neonates is based on various studies in both term $^{5}$ and preterm neonates. ${ }^{6-10}$

A recent meta-analysis reviewed outcomes for infants $<29$ weeks gestation randomized to resuscitation with low $(\leq 0.3)$ versus high $(\geq 0.6)$ fraction of inspired oxygen at delivery. ${ }^{11}$ The meta-analysis included infants enrolled in eight studies conducted from 2005 to 2014 (six masked and two unmasked); with 251 infants enrolled in the low oxygen and 253 infants enrolled in the high oxygen groups. There was no differences in outcome measures such as, bronchopulmonary dysplasia (BPD), intraventricular hemorrhage, retinopathy of prematurity (ROP), patent ductus arteriosus, necrotizing enterocolitis and overall mortality ${ }^{11}$ between the two groups. However, mortality was lower in the low oxygen arm in the masked studies and higher in the low oxygen arm in unmasked studies. ${ }^{11}$ Opposite effects on mortality from masking or unmasking, suggest an element of bias built into these studies.

The largest study to date to assess both short-term and long-term outcomes of $21 \%$ (room air) versus $100 \%$ oxygen at resuscitation in premature neonates was stopped due to the loss of equipoise for the use of $100 \%$ oxygen. ${ }^{12}$ This particular study recruited 292 infants over six years and the recruitment was stopped by Data Safety Monitoring Board (DSMB), as infants $<28$ weeks gestational age (GA) who received room air resuscitation had higher hospital mortality (RA resuscitation: 10/46 (22\%) versus $100 \%$ $\mathrm{O}_{2}: 3 / 54$ (6\%); CI: 1.1-13.4). ${ }^{12}$ In the same study, deaths was not different between the groups for all infants $<32$ weeks GA. Small sample size and inability to power the study to analyze infants $<28$ weeks GA limits the conclusions of the study. Nonetheless, this study brings to focus that resuscitation with lower concentration of oxygen may lead to higher mortality compared to using $100 \%$ $\mathrm{O}_{2}$ in premature infants.

Almost half of the premature infants enrolled in oxygen resuscitation studies did not reach a $\mathrm{SpO}_{2}$ of $80 \%$ at 5 minutes and this was associated with increased risk of intraventricular hemorrhage and bradycardia $(\mathrm{HR}<100 / \mathrm{min})$ at five minutes of age. ${ }^{13}$ Both of the above factors were associated with lower gestational age, suggesting these infants are sick soon after birth with immature lungs, a proxy for lower $\mathrm{SpO}_{2}$. The morbidity and mortality data of the three studies described above is summarized in Table 1.

In a retrospective analysis from Canadian neonatal intensive care units (NICUs), similar conclusions relating to oxygen concentration at resuscitation in premature neonates were noted. ${ }^{14}$ The study compared neonatal outcomes in infants born at $\leq 27$ weeks GA who received $<100 \% \mathrm{O}_{2}$ (typically $21-40 \% \mathrm{O}_{2}$ ) during delivery room resuscitation to infants that received $100 \% \mathrm{O}_{2}$ at resuscitation (historical controls prior to 2006). The study found that the adjusted odds ratio (AOR) for primary outcome of severe neurologic injury or death was higher in the titratable oxygen group compared to $100 \% \mathrm{O}_{2}$ group (AOR 1.36; CI: 1.11-1.36). ${ }^{14}$ A similar increase was also noted in infants resuscitated with $21 \%$ $\mathrm{O}_{2}$ and titrated upwards compared to $100 \% \mathrm{O}_{2}$ group (AOR 1.33; CI: 1.04-1.69). Despite the infants being of higher birth weight and lower score for neonatal acute physiology (SNAP) scores, resuscitation with less than $100 \%$ oxygen led to worse primary outcome. ${ }^{14}$ A change in practice to use room air or intermediate concentration of oxygen at resuscitation was associated with a higher risk of severe neurologic injury or death among preterm infants $\leq 27$ weeks GA.

\begin{tabular}{|c|c|c|c|}
\hline Study & Methods & Mortality & Morbidity \\
\hline Oei JL et al" & $\begin{array}{l}\text { All deaths - } \\
34 / 257(\leq 0.3) \text { vs. } 32 / 258(\geq 0.6)\end{array}$ & $\begin{array}{l}\text { NS - Mortality not different between } \\
\text { groups }\end{array}$ & \multirow{3}{*}{$\begin{array}{l}\text { No difference in BPD, } \\
\text { IVH, PDA, NEC, ROP }\end{array}$} \\
\hline $\begin{array}{l}\text { All studies with } \leq 0.3 \text { or } \geq 0.6 \mathrm{FiO}_{2} \text { at } \\
\text { resuscitation }\end{array}$ & $\begin{array}{l}\text { Death (Masked studies }-3)- \\
10 / 98(\leq 0.3) \text { vs. } 18 / 83(\geq 0.6)\end{array}$ & $p=0.03 ;$ death higher in $\geq 0.6 \mathrm{FiO}_{2}$ group & \\
\hline (Meta-analysis of 8 studies) & $\begin{array}{l}\text { Death (Unmasked studies }-5)- \\
24 / 153(\leq 0.3) \text { vs. } 14 / 175(\geq 0.6)\end{array}$ & $p=0.03 ;$ death higher in $\leq 0.3 \mathrm{FiO}_{2}$ group & \\
\hline Oei JL et al ${ }^{12}$ & $\begin{array}{l}\text { All deaths - } \\
14 / 144(0.21) \text { vs. } 6 / 143(1.0)\end{array}$ & NS & \multirow{3}{*}{$\begin{array}{l}\text { No difference in BPD, } \\
\text { IVH, PDA, NEC, ROP }\end{array}$} \\
\hline \multirow[t]{2}{*}{$\begin{array}{l}\mathrm{RCT}-21 \% \mathrm{O}_{2} \text { vs. } 100 \% \mathrm{O}_{2} \text { at } \\
\text { resuscitation }\end{array}$} & $\begin{array}{l}\text { Deaths <28 wks GA - } \\
10 / 46(0.21) \text { vs. } 4 / 54(1.0)\end{array}$ & $p=0.04$; higher death in $0.21 \mathrm{FiO}_{2}$ & \\
\hline & $\begin{array}{l}\text { Deaths: } 28-31 \text { wks GA- } \\
4 / 98(0.21) \text { vs. } 2 / 89(1.0)\end{array}$ & NS & \\
\hline Oei JL et $\mathbf{a l}^{13}$ & 768 infants of lower $(\leq 0.3)$ or higher $(\geq 0.6)$ & & \\
\hline $\begin{array}{l}\text { Relationship between } \mathrm{SpO}_{2} \text { at } 5 \mathrm{~min} \text {, } \\
\text { death and } \mathrm{IVH} \\
\text { (Meta-analysis of } 8 \text { studies) }\end{array}$ & $\begin{array}{l}\mathrm{FiO}_{2} \text { for resuscitation. } \\
\text { Infants with } \mathrm{SpO}_{2}<80 \text { at } 5 \mathrm{~min} \text { : } \\
\text { More premature } \\
\text { Lower birth weight } \\
\text { More likely to receive } \leq 0.3 \mathrm{FiO}_{2}\end{array}$ & $\begin{array}{l}\text { Lower GA, lower birth weight and } 5 \text { min } \\
H R<100 \text { significantly associated with death }\end{array}$ & $\begin{array}{l}\mathrm{SpO}_{2}<80 \text { associated with } \\
\uparrow \mathrm{IVH}\end{array}$ \\
\hline
\end{tabular}


membrane disease (HMD) and BPD. Multiple studies have demonstrated that exposure to hyperoxia during critical periods of lung development, impairs alveolar development with inhibition of secondary crest formation. ${ }^{15-17}$ Despite the recently conducted randomized trials comparing high $\left(\mathrm{SpO}_{2}\right.$ : 91-95\%) versus low $\left(\mathrm{SpO}_{2}\right.$ : $85-89 \%$ ) oxygen saturation targets, optimal oxygen saturation range in premature infants has remained elusive. Among the three oxygen saturation trials, infants randomized to the higher $\mathrm{SpO}_{2}$ group (91-95\%) had a significantly higher incidence of severe ROP and infants randomized to the lower $\mathrm{SpO}_{2}$ group $(85-89 \%)$ had higher mortality at NICU discharge. ${ }^{18-20}$ Canadian oxygenation trial did not demonstrate any difference in mortality between the low and the high $\mathrm{SpO}_{2}$ groups. ${ }^{21}$ The morbidity and mortality outcomes for the oxygen saturation trials in premature infants are summarized in Table 2. Post-hoc study of the SUPPORT trial ${ }^{19}$ found evidence of an interaction between small for gestational age and lower oxygen saturation targets $\left(\mathrm{SpO}_{2}: 85-89 \%\right)$ with increased mortality in these infants. ${ }^{22}$ Oxygen use and optimal saturation targets in premature infants is as much an enigma as oxygen use and optimal saturation targets at resuscitation of these infants.

The saturation targets in premature infants in the first ten minutes of life are extrapolation from birth nomograms in term infants. The physiology of oxyhemoglobin curve in preterm newborns likely differ compared to term infants. ${ }^{23-25}$ Maintaining similar saturations in both term and preterm infants may lead to higher oxygen delivery, higher oxidant load and downregulation of dent causative effect of inspired oxygen concentration on hyaline

\begin{tabular}{|c|c|c|c|}
\hline Study & Methods & Morbidity & ND Outcome / Mortality \\
\hline SUPPORT Trial' ${ }^{19}$ & $\begin{array}{l}\mathrm{SPO}_{2}: 85-89(\mathrm{n}=654)(\mathrm{LOSG}) \\
\mathrm{SPO}_{2}: 91-95(\mathrm{n}=662(\mathrm{HOSG})\end{array}$ & $\begin{array}{l}\text { ROP - Significantly lower in LOSG - } \\
41 / 475 \text { (8.6\% vs } 91 / 509(17.9 \%) \\
\text { BPD - Significantly higher in HOSG - } \\
203 / 540(37.6 \% \text { vs } 265 / 568(46.7 \%) \\
\text { NS - IVH, NEC, PDA }\end{array}$ & $\begin{array}{l}\text { Death before discharge - Significantly higher } \\
\text { in LOSG - 130/654 (19.9\% vs. } 107 / 662(16.2 \%)\end{array}$ \\
\hline SUPPORT Trial ${ }^{27}$ & $\begin{array}{l}\mathrm{SpO}_{2}: 85-89(\mathrm{n}=654)(\mathrm{LOSG}) \\
\mathrm{SpO}_{2}: 91-95(\mathrm{n}=662 \text { (HOSG) } \\
\text { ND Outcome Study }\end{array}$ & & $\begin{array}{l}\text { Death / NDI - NS ( } 185 / 6 / 2 \text { (30.2\%) vs. I7I/622 } \\
(27.5 \%) \\
\text { Death - higher in LOSG (140/633 (22.1\%) vs. } \\
\text { I I8/648 (18.2\%) } \\
\text { NDI - NS (45/472 (9.5\%) vs. } 53 / 504 \text { (10.5\%) }\end{array}$ \\
\hline COT Trial ${ }^{21}$ & $\begin{array}{l}\mathrm{SpO}_{2}: 85-89(n=578)(\mathrm{LOSG}) \\
\mathrm{SPO}_{2}: 91-95(\mathrm{n}=569(\mathrm{HOSG}) \\
\mathrm{ND} \text { Outcome Study }\end{array}$ & & $\begin{array}{l}\text { Composite Death / Disability - NS ( } 298 / 578 \\
(51.6 \%) \text { vs. } 283 / 569 \text { ( } 49.7 \%) \\
\text { Death before } 18 \text { months - NS ( } 97 / 585 \text { (16.6\%) } \\
\text { vs. } 88 / 577 \text { (15.3\%) } \\
\text { Any disability - NS }\end{array}$ \\
\hline BOOST Trial ${ }^{20}$ & $\begin{array}{l}\mathrm{SPO}_{2}: 85-89(\mathrm{n}=654)(\mathrm{LOSG}) \\
\mathrm{SPO}_{2}: 91-95(\mathrm{n}=662(\mathrm{HOSG})\end{array}$ & $\begin{array}{l}\text { ROP (pooled data) - Significantly lower } \\
\text { in LOSG - I I0/1035 (10.6\% vs I4I//1044 } \\
\text { (13.5\%) } \\
\text { NEC (pooled data) - Significantly higher } \\
\text { in LOSG - I27/I22I (10.4\% vs } 97 / 1217 \\
(8 \%) \\
\text { NS - IVH, PDA, BPD }\end{array}$ & $\begin{array}{l}\text { Death before discharge (revised algorithm) - } \\
\text { Significantly higher in LOSG - } 137 / 592(23.1 \%) \\
\text { vs. } 94 / 590 \text { (15.9\%) }\end{array}$ \\
\hline
\end{tabular}


hypoxia inducible factor (HIF-1) and vascular endothelial growth factor (VEGF) expression in premature infants. As molecular signaling and growth at transition are distinct in extremely preterm infants, so are oxygenation needs and $\mathrm{SpO}_{2}$ in preterm infants. There is great variation in the initiating oxygen concentration at birth $\left(21 \% \mathrm{O}_{2}\right.$ to $\left.30 \% \mathrm{O}_{2}\right)$. Titrating oxygen soon after birth is dependent on reliable pulse oximetry tracing. Once the tracing is noted, how the provider responds to titrate oxygen is an extremely variable component, with no two providers responding the same way in a given situation. Postnatal saturations and events are variables over the infant's course in the NICU that can influence both short-term and long-term outcomes. A small for gestational age infant resuscitated in $21 \% \mathrm{O}_{2}$ with relatively low postnatal saturations is more likely to experience mortality. Physiological, clinical and practical variables pose hurdles in standardization of oxygen concentration at resuscitation. In addition, transitioning the extremely premature infant to a similar oxygen environment as the term infant in the face of physiological and biological immaturity is a great challenge.

The current NRP guidelines states 'preterm infants $<35$ weeks GA should be initiated with $21-30 \% \mathrm{O}_{2}$ and the oxygen concentration to be titrated to achieve preductal oxygen saturations approximating the interquartile range measured in healthy term infants'. ${ }^{4}$ Did the pendulum swing from $100 \% \mathrm{O}_{2}$ to $21 \% \mathrm{O}_{2}$ too quickly, without adequately addressing the unique physiological needs of the developing fetus? None of the studies has addressed clinical or neuro-developmental outcomes based on NRP recommended guidelines in rigorous trials. No two studies conducted prior to $2010\left(21 \% \mathrm{O}_{2}\right.$ or $30 \% \mathrm{O}_{2}$ resuscitation), on which the NRP recommendations were based, had similar oxygen saturation nor $\mathrm{FiO}_{2}$ weaning protocols at resuscitation. The only study to demonstrate benefits from initiating resuscitation with $30 \% \mathrm{O}_{2}$ on the incidence of BPD was conducted prior to $2010^{9}$; the oxygen concentration was weaned to achieve $\mathrm{SpO}_{2}$ targets of $75 \%$ at 5 minutes and $85 \%$ at 10 minutes $^{9}$, different from NRP guidelines. European consensus guidelines for the management of respiratory distress syndrome recommends that initial concentration of $30 \%$ $\mathrm{O}_{2}$ for infants $<28$ weeks $\mathrm{GA}$ and $21-30 \% \mathrm{O}_{2}$ for 28-31 week GA infants; $\mathrm{FiO}_{2}$ titrated guided by pulse oximetry from birth. ${ }^{26} \mathrm{How}$ ever, NRP recommends $21-30 \% \mathrm{O}_{2}$ for premature infants across all gestational ages. ${ }^{1}$ Is it time to change NRP guidelines to resuscitate preterm infants with oxygen $>21 \% \mathrm{O}_{2}$, preferably $30 \% \mathrm{O}_{2}$ to $40 \%$ $\mathrm{O}_{2}$ and titrate it up or down to maintain NRP recommended preductal $\mathrm{SpO}_{2}$ targets. At this time, there is insufficient evidence to indicate that resuscitation with lower oxygen concentration $(\leq 30 \%$ $\mathrm{O}_{2}$ ) at birth will decrease BPD or other clinical outcomes such as severe intraventricular hemorrhage, retinopathy of prematurity (Stage $\geq 3$ ), necrotizing enterocolitis or patent ductus arteriosus. Alternatively, is it time to evaluate the knowledge gap by large-scale multicenter trials to assess both short-term and long-term clinical and neuro-developmental outcomes. Should we wait for data from more centers post guidelines on clinical outcomes and mortality? With any of these approaches, the answer will not come easy for physicians caring for premature neonates. Fetus has developed a unique physiology over time to meet the developmental needs in utero; mimicking similar environment ex utero is probably not the answer from the above studies. Titrating the oxygen concentration to defined saturation targets with pulse oximetry is the most favorable option for now until studies find evidence otherwise.

\section{REFERENCES}

1. Kattwinkel J, Perlman JM, Aziz K, et al. Neonatal resuscitation: 2010 American Heart Association Guidelines for Cardiopulmonary Resuscitation and Emergency Cardiovascular Care. Pediatrics. 2010; 126(5): e1400-e1413. doi: 10.1542/peds.2010-2972E

2. Dawson JA, Kamlin CO, Vento M, et al. Defining the reference range for oxygen saturation for infants after birth. Pediatrics. 2010; 125(6): e1340-e1347. doi: 10.1542/peds.2009-1510

3. Kamlin CO, O’Donnell CP, Davis PG, Morley CJ. Oxygen saturation in healthy infants immediately after birth. J Pediatr. 2006; 148(5): 585-589. doi: 10.1016/j.jpeds.2005.12.050

4. Perlman JM, Wyllie J, Kattwinkel J, et al. Part 7: Neonatal Resuscitation: 2015 International Consensus on Cardiopulmonary Resuscitation and Emergency Cardiovascular Care Science with Treatment Recommendations. Circulation. 2015; 132(16 Suppl 1): S204-S241. doi: 10.1016/j.resuscitation.2015.07.045

5. Mariani G, Dik PB, Ezquer A, et al. Pre-ductal and post-ductal O2 saturation in healthy term neonates after birth. J Pediatr. 2007; 150(4): 418-421. doi: 10.1016/j.jpeds.2006.12.015

6. Kapadia VS, Chalak LF, Sparks JE, Allen JR, Savani RC, Wyckoff $\mathrm{MH}$. Resuscitation of preterm neonates with limited versus high oxygen strategy. Pediatrics. 2013; 132(6): e1488-e1496.

7. Rabi Y, Singhal N, Nettel-Aguirre A. Room-air versus oxygen administration for resuscitation of preterm infants: The ROAR study. Pediatrics. 2011; 128(2): e374-e381. doi: 10.1542/peds. 2010-3130

8. Rook D, Schierbeek H, Vento M. Resuscitation of preterm infants with different inspired oxygen fractions. J Pediatr. 2014; 164(6): 1322-1326 e3. doi: 10.1016/j.jpeds.2014.02.019

9. Vento M, Moro M, Escrig R, et al. Preterm resuscitation with low oxygen causes less oxidative stress, inflammation, and chronic lung disease. Pediatrics. 2009; 124(3): e439-e449. doi: 10.1542/ peds.2009-0434

10. Wang CL, Anderson C, Leone TA, Rich W, Govindaswami B, Finer NN. Resuscitation of preterm neonates by using room air or 100\% oxygen. Pediatrics. 2008; 121(6): 1083-1089. doi: 10.1542/ peds. $2007-1460$

11. Oei JL, Vento M, Rabi Y, et al. Higher or lower oxygen for delivery room resuscitation of preterm infants below 28 completed weeks gestation: A meta-analysis. Arch Dis Child Fetal Neonatal Ed. 2016; 102(1): F24-F30 doi: 10.1136/archdischild-2016-310435

12. Oei JL, Saugstad OD, Lui K, et al. Targeted oxygen in the resuscitation of preterm infants, a randomized clinical trial. Pediatrics. 
2017; 139(1). pii: e20161452. doi: 10.1542/peds.2016-1452

13. Oei JL, Finer NN, Saugstad OD, et al. Outcomes of oxygen saturation targeting during delivery room stabilisation of preterm infants. Arch Dis Child Fetal Neonatal Ed. 2017. doi: 10.1136/archdischild-2016-312366

14. Rabi Y, Lodha A, Soraisham A, Singhal N, Barrington K, Shah PS. Outcomes of preterm infants following the introduction of room air resuscitation. Resuscitation. 2015; 96: 252-259. doi: 10.1016/j.resuscitation.2015.08.012

15. Kumar VH, Lakshminrusimha S, Kishkurno S, et al. Neonatal hyperoxia increases airway reactivity and inflammation in adult mice. Pediatr Pulmonol. 2016; 51(11): 1131-1141. doi: 10.1016/j.resuscitation.2015.08.012

16. Veness-Meehan KA, Bottone FG, Jr., Stiles AD. Effects of retinoic acid on airspace development and lung collagen in hyperoxia-exposed newborn rats. Pediatr Res. 2000; 48(4): 434-444. doi: 10.1203/00006450-200010000-00004

17. Warner BB, Stuart LA, Papes RA, Wispe JR. Functional and pathological effects of prolonged hyperoxia in neonatal mice. $\mathrm{Am}$ J Physiol. 1998; 275(1 Pt 1): L110-L117.

18. Australia BI, Tarnow-Mordi W, Stenson B, et al; United Kingdom Collaborative Group. Outcomes of two trials of oxygensaturation targets in preterm infants. N Engl J Med. 2016; 374(8): 749-760. doi: 10.1056/NEJMoa1514212

19. Carlo WA, Finer NN, Walsh MC, et al. Target ranges of oxygen saturation in extremely preterm infants. N Engl J Med. 2010; 362(21): 1959-1969. doi: 10.1056/NEJMoa0911781

20. Group BIUKC, Group BIAC, Group BINZC; Stenson BJ,
Tarnow-Mordi WO, Darlow BA, et al. Oxygen saturation and outcomes in preterm infants. N Engl J Med. 2013; 368(22): 2094-2104. doi: 10.1056/NEJMoa1302298

21. Schmidt B, Whyte RK, Asztalos EV, et al; Canadian Oxygen Trial (COT) Group. Effects of targeting higher vs lower arterial oxygen saturations on death or disability in extremely preterm infants: A randomized clinical trial. JAMA. 2013; 309(20): 21112120. doi: 10.1001/jama.2013.5555

22. Walsh MC, Di Fiore JM, Martin RJ, Gantz M, Carlo WA, Finer $\mathrm{N}$. Association of oxygen target and growth status with increased mortality in small for gestational age infants: Further analysis of the surfactant, positive pressure and pulse oximetry randomized trial. JAMA Pediatr. 2016; 170(3): 292-294. doi: 10.1001/jamapediatrics.2015.3794

23. Finne PH, Halvorsen S. Regulation of erythropoiesis in the fetus and newborn. Arch Dis Child. 1972; 47(255): 683-687.

24. Von Kohorn I, Ehrenkranz RA. Anemia in the preterm infant: erythropoietin versus erythrocyte transfusion--it's not that simple. Clin Perinatol. 2009; 36(1): 111-123. doi: 10.1016/j.clp.2008.09.009

25. Dudell G, Cornish JD, Bartlett RH. What constitutes adequate oxygenation? Pediatrics. 1990; 85(1): 39-41.

26. Sweet DG, Carnielli V, Greisen G, et al. European consensus guidelines on the management of respiratory distress syndrome - 2016 update. Neonatology. 2017; 111(2): 107-125. doi: $10.1159 / 000448985$

27. Vaucher YE, Peralta-Carcelen M, Finer NN, et al. Neurodevelopmental outcomes in the early CPAP and pulse oximetry trial. N Engl J Med. 2012; 367(26): 2495-2504. doi: 10.1056/NEJMoa1208506 